\title{
DETERMINANTS AND IMPACT OF FINANCIAL SECTOR FDI TO EMERGING ECONOMIES: A HOME COUNTRY'S PERSPECTIVE ${ }^{1}$
}

\author{
Alicia García Herrero and Daniel Navia Simón ${ }^{2}$
}

September 2003

\begin{abstract}
This paper reviews the theoretical literature explaining financial FDI, as well as the empirical results on the determinants of financial FDI and its potential effects for the home country. From this revision, we conclude that, at the present stage, the existing theoretical paradigms need to be adapted to explain the recent surge in international banks' local operations in emerging countries financial sectors. Macroeconomic and risk diversification theories would seem particularly well-suited to explain this reality. The empirical literature on financial FDI has concentrated on bank-specific factors and much less so on macroeconomic determinants, particularly push factors where generally only general FDI literature is available. The survey draws on this literature in those cases where no specific results for financial FDI exist. Finally, the effects of financial FDI on the home country are virtually unknown. The literature on general FDI has focused on employment, trade and investment effects, yet the consequences on the profitability and systemic risk of home's financial system remain a topic for debate.
\end{abstract}

\footnotetext{
${ }^{1}$ This paper was prepared as background material for the Working Group on Financial FDI of the BIS Committee of the Global Financial System (CGFS)

${ }^{2}$ Both authors are affiliated with Banco de España (navia@bde.es and alicia.garcia-herrero@bde.es). Opinions are theirs and not of the institution they represent. The authors wish to thank members of the CGFS working group on Financial FDI and participants to the seminar organized at Banco de España for their valuable comments. Remaining errors are the responsibility of the authors.
} 


\section{INTRODUCTION}

During the 1990s, foreign involvement in the financial sector of emerging economies rose substantially. By the end of the decade, foreign-owned banks in Central and Eastern Europe accounted for an average of $70 \%$ of bank assets and $40 \%$ in Latin America (Mathieson and Roldós (2001)). The growth of foreign banking activities in emerging economies is not an isolated phenomenon. It is part of the well documented increase in foreign direct investment (FDI) flows towards emerging economies during the last decade. This has largely been led by mergers and acquisitions, reflecting the extensive privatization of state-owned assets in Latin America and Central and Eastern Europe and the sale of distressed banking and corporate assets in several Asian economies following the 1997 crisis $^{3}$.

The expansion of international banks into emerging economies has resulted into a renewed interest in the causes and consequences of financial FDI. A good part of the existing literature was developed in the 1970s and early 1980s, with the objective of explaining the so-called "second-wave" of financial institutions' international expansion, which started in the $1960 \mathrm{~s}^{4}$. This concentrated in developed countries, although there was also a surge in bank loans to emerging countries. As will be explained in more detail in the next section, during the second half of the 1990s, banks have started local operations in a large number of emerging markets, while others have renewed their cross-border operations, which had been severely cut back after the debt crisis of the 1980s. This recent expansion, sometimes called "third wave", has mainly been analysed from the host country's point of view (i.e., in terms of gains in the amount of loanable funds, efficiency or financial stability in the host contry). The main novelty of this article is to take a home country focus in reviewing the literature on the determinants and effects of financial sector FDI. It also takes a broad perspective, starting with the literature of the 1970s.

The paper reviews the theoretical literature explaining financial FDI, as well as the empirical literature on its determinants and effects for the home country. Where no specific literature exists, we draw from existing findings for general FDI and draw conclusions when potentially applicable to financial FDI. Finally, we make suggestions on further research in areas where no specific literature exists or no clear consensus arises.

\footnotetext{
${ }^{3}$ See International Monetary Fund (2003) for further details

${ }^{4}$ The first was in the nineteenth century. See Jones (1990)
} 
The paper proceeds as follows. Section 2 briefly describes the main developments in financial FDI in emerging countries. Section 3 reviews the main theories that attempt to explain why a bank operates abroad. Section 4 reports on the main determinants of financial FDI found in the empirical literature. Section 5 is devoted to the effects of FDI on the home country. The sixth, and last, section draws some conclusions and presents suggestions for future research.

\section{FINANCIAL FDI IN EMERGING MARKETS: HOW HAS IT HAPPENED ${ }^{5}$}

The "third wave" of international banks" activities during the second half of the 1990s has implied that operations of international banks in emerging countries, measured by their total foreign claims from the Bank for International Settlements statistics ${ }^{6}$ have more than doubled when compared to the early 1980s, and now amount to approximately 1,4 trillion US\$. Although large compared to the previous decade, it is still just about one eighth of foreign claims among developed countries ${ }^{7}$.

This "third wave" has been characterized by a surge in local operations in emerging markets, reaching the current mark of $40 \%$ of all foreign claims to emerging countries for a meagre $5 \%$ in the early 1980s. In addition, there has been a more frequent use of subsidiaries, a consequence of the retail orientation of their business, in contrast to the wholesale nature of previous internationalization waves. Even if international claims to emerging countries (mainly cross-border claims ${ }^{8}$ ) are still comparatively higher today, at $60 \%$ of total foreign claims, their weight was in a clear downward trend, at least until mid-2001 ${ }^{9}$ (see Graph 1).

\footnotetext{
${ }^{5}$ This section is drawn from Gallego, García Herrero and Luna (2003)

${ }^{6}$ These consolidated statistics include cross-border claims and local claims in domestic and foreign currencies.

${ }^{7}$ Operations in off-shore centres are excluded.

${ }^{8}$ But it also includes local claims in foreign currency.

${ }^{9}$ It should be noted that the BIS consolidated data inevitably bias downwards local banking activity, since foreigncurrency denominated local claims are treated as if they were cross-border lending (i.e., they are included in banks' international claims). This is particularly relevant for highly dollarized emerging countries, many of which are in the Latin American region
} 


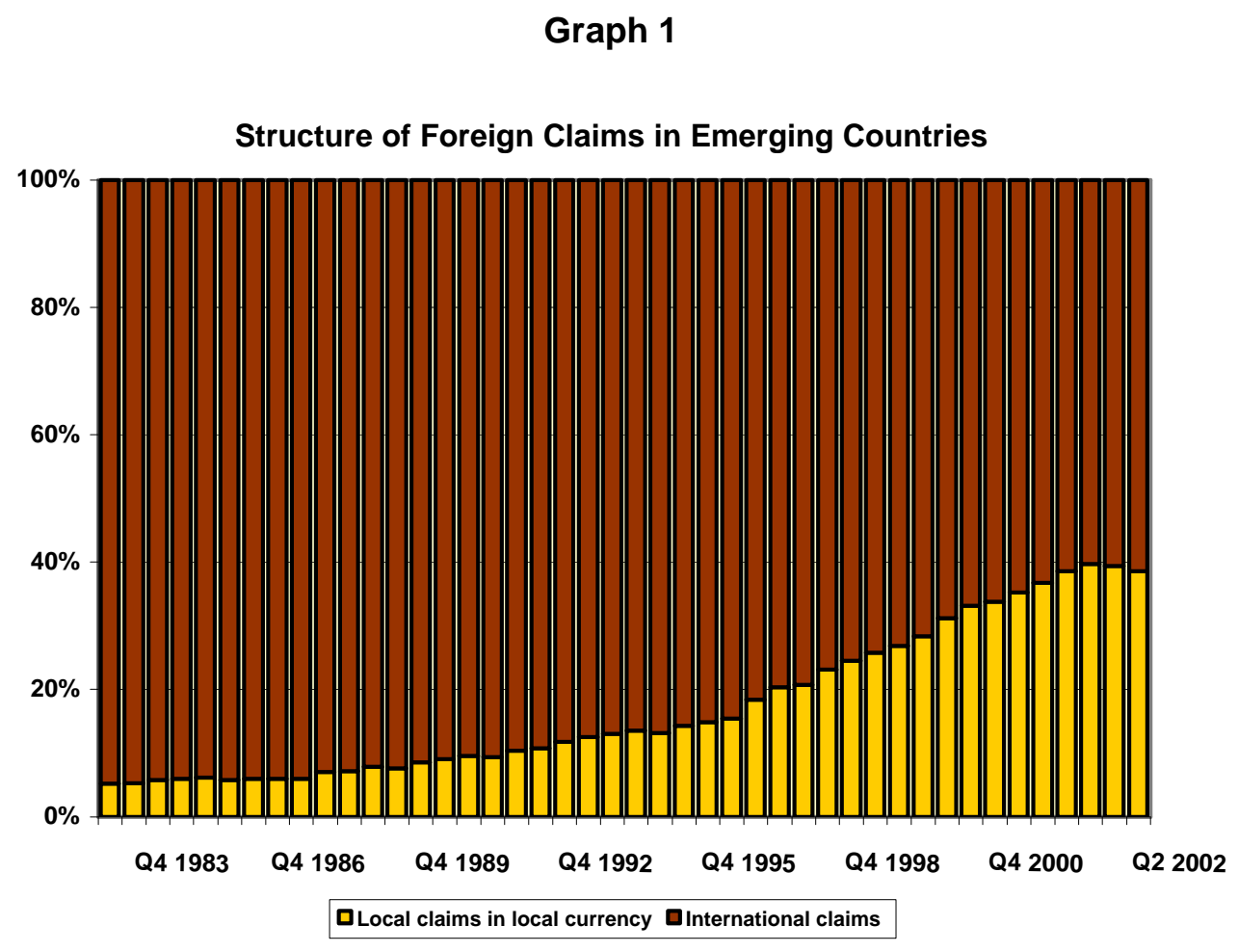

"Going local" appears to be the leading strategy of international banks which want to operate in emerging countries ${ }^{10}$. Local claims in local currency have risen sharply in Asia, Central and Eastern Europe, Africa and especially Latin America although the level is different. In Latin America, local claims in local currency are currently over $50 \%$ of foreign claims from levels below $5 \%$ in the early eighties. This percentage is comparatively lower, yet very significant, for Central and Eastern Europe and Emerging Asia (see Graphs 2, 3 and 4). This, coupled with the relatively small size of the banking systems in Latin America and Central and Eastern Europe, explains that foreign-owned banks represent over half of the banking system in many of these countries, particularly in Central and Eastern Europe ${ }^{11}$. In contrast, total foreign-owned assets have decreased in several African countries, particularly the poorest ones. This seems to indicate that bank internationalization is concentrated in medium- to high-income countries (De Nicoló et al (2003)).

\footnotetext{
${ }^{10}$ See also Clarke et al. (2001)

${ }^{11}$ See García Herrero et al. (2002)
} 


\section{Graph 2}

\section{Structure of Foreign Claims in Latinoamerica}

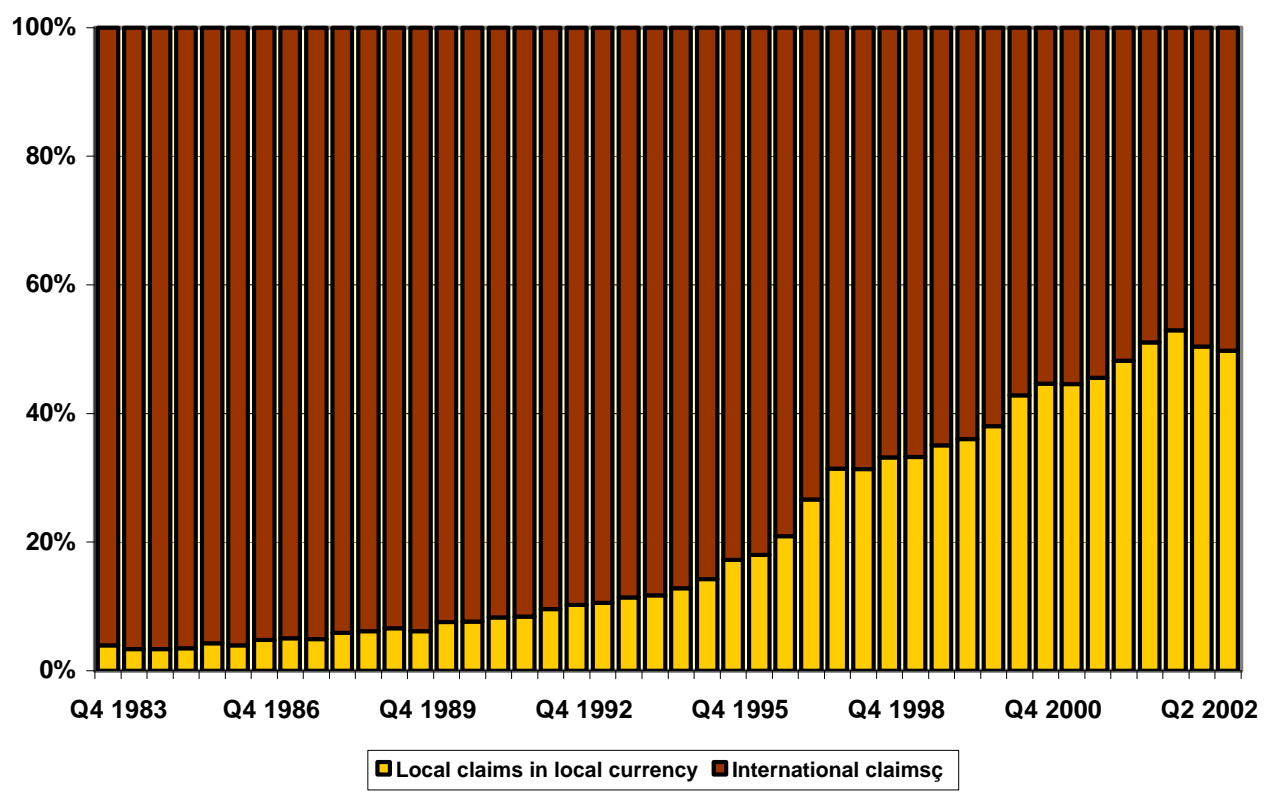

\section{Graph 3}

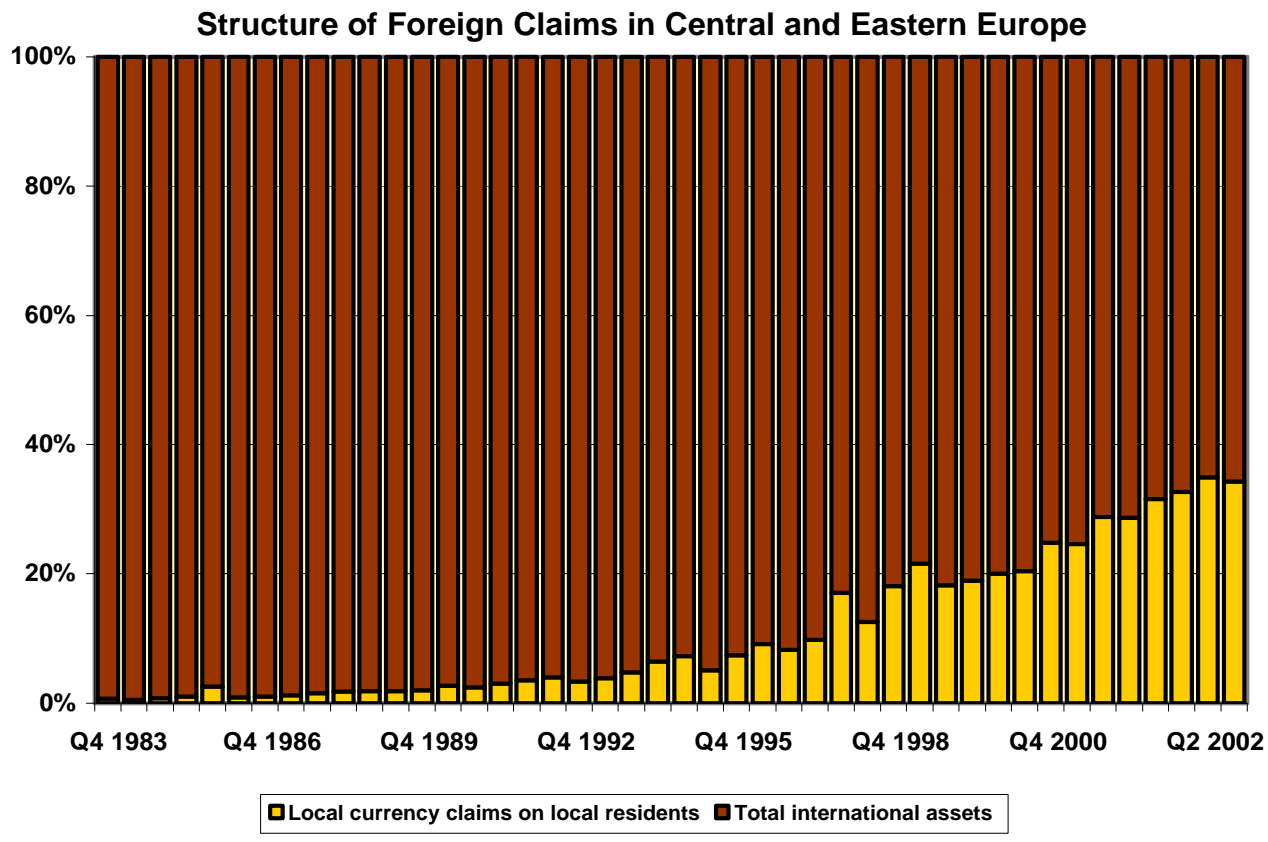




\section{Graph 4}

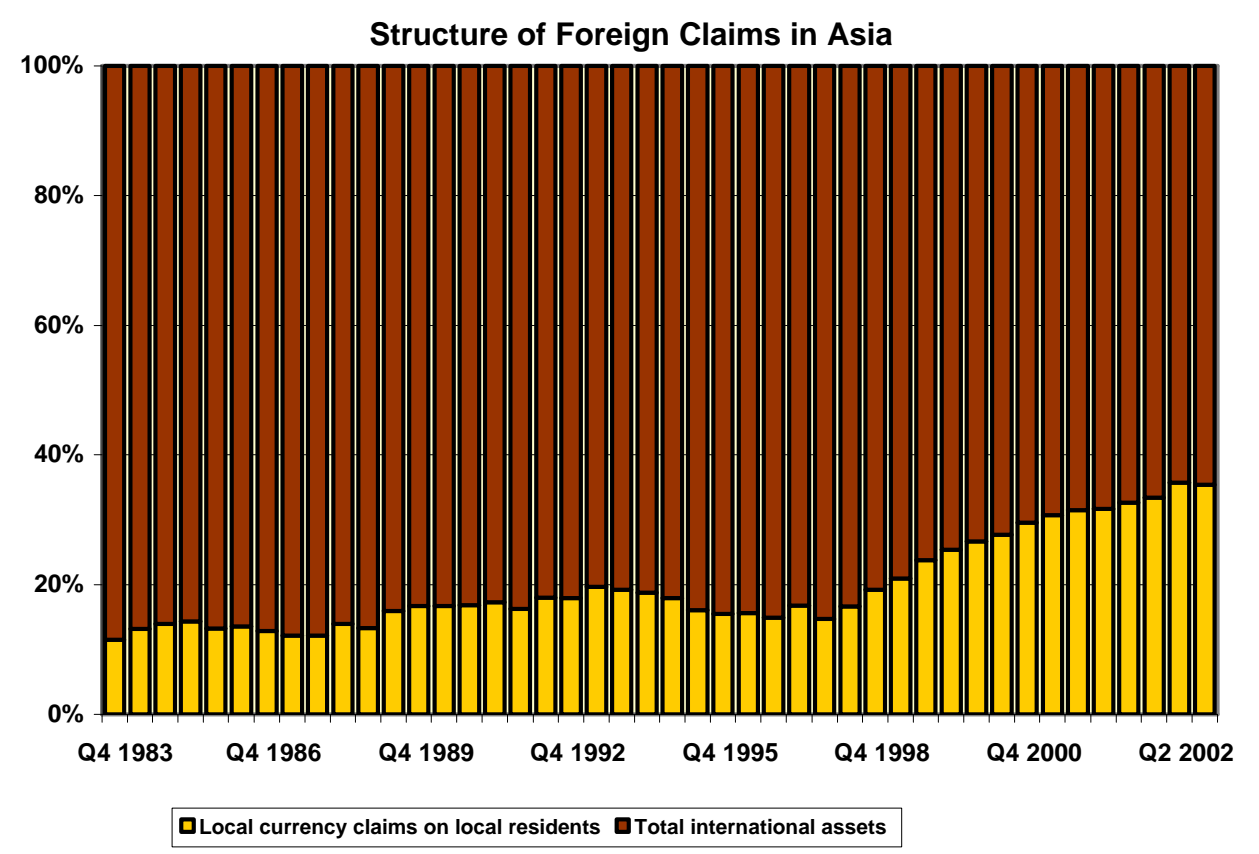

\section{THEORIES EXPLAINING FINANCIAL SECTOR FDI}

If one takes the theoretical literature on general FDI, there are a number of macroeconomic drivers, which may explain a decision to invest abroad. This is hardly the case for financial FDI, where exiting theories mainly focus on microeconomic or organizational aspects. We start describing the latter and then move to a review of macroeconomic theories of general FDI to shed some light on the potential applicability of these theories for financial FDI (for a visual outline of the different theories see Diagram 1 at the end of the Section).

\section{Microeconomic/behavioural framework}

Virtually all existing theoretical paradigms focus on the comparison of benefits and costs of the investment decision. As with any kind of investment, the bank will face uncertainty about the expected profits of such decision, and even expected costs. On the cost side, Hymer (1969) introduces the widely accepted notion that foreign banks face significant cost disadvantages when compared with local competition. These additional costs can arise as a consequence of cultural differences, legal barriers or increased control problems, just to cite a few examples. Therefore, in 
order to operate profitably in a foreign market, international banks must be able to realize gains that are unavailable to local competitors. These expected gains, to be realized when operating in a foreign financial sector, generally stem from (i) competitive advantage factors, (ii) efficiencies that cannot be attained operating exclusively in local markets; and (iii) geographical risk diversification.

Regarding comparative advantages, innovative products, better intermediation technologies or superior management quality are among the frequently cited both by the eclectic theory of the multinational corporations (see Dunning (1977) and Gray and Gray (1981) for an early application to multinational banking ${ }^{12}$ ) and the internalisation theory (Buckley and Casson (1991) ${ }^{13}$ ). Some authors argue that these factors, however, are not very relevant in the case of financial FDI, or at least not permanently, because of the need to assume that financial firms have intangible assets which cannot be imitated, in a generally highly competitive sector, such as the banking system (Dufey and Giddy (1981)) or because management quality can easily be transferred (Merret (1990) ${ }^{14}$ ). Nonetheless, the case against the persistence of these competitive advantages is considerably weaker for emerging market economies, where the dominance of government-owned banks has generally resulted in low competition in the banking sector (Marichal (1997)).

Other comparative advantages may be crucial for a bank to operate abroad. The most obvious one is information $^{15}$. Firms prefer to do business with a reduced numbers of banks, so as not to reveal sensitive financial information to too many financial firms (Nigh, Cho and Krishnan (1986) and Casson (1990)). Therefore, once a bank has established a relationship with a firm, it has a competitive advantage in serving that firm's operations in foreign markets. It could also be argued that the recent shift from cross-border lending towards foreign banks' local activity in emerging countries is a consequence of the increased importance of information in the banking business.

\footnotetext{
12 This theory postulates that FDI will be undertaken by a firm when the following conditions are met: (i) Foreign investors have firm-specific advantages over host country firms. Typical examples of firm-specific advantages often cited in the literature are proprietary technology, trade marks, better management or control of market entry. (ii) Foreign firms have some intangible assets with lower exploitation costs that licensing or selling a patent, which give them an edge over local firms. This is generally called "internalisation" and has been frequently used in the theories explaining financial system FDI. Good examples are imperfect markets for informational assets and quality concerns. (iii) Locational advantages exist, which stem from the host country's characteristics

${ }^{13}$ As a departure from the eclectic theory, internalization arguments stress the advantages of multinational firms stemming from the possibility of limiting the cost of market failures by carrying out a share of their transactions within the boundaries of the firm. Williams (1997) presents a recent review of this paradigm and argues that most of the theoretical approaches to multinational banking can be encompassed as subsets of internalization theory

${ }^{14} \mathrm{He}$ finds that banks face significant difficulties in order to retain skilled staff when operating in a foreign country

${ }^{15}$ The role of information has been formalized recently for general FDI (Mody, Razin and Sadka, 2003))
} 
One of the most well-known ways of exploiting the comparative advantages stemming from private information in a foreign market is to "follow the client". This implies that banks expand in those countries where their corporate clients choose to invest so as to be able to offer them the services they need (Brimmer and Dahl (1975), Gray and Gray (1981), Ball and Tschoegl (1982)). Moreover, a bank has a clear interest in keeping other financial institutions away from developing a relationship with its corporate clients, because this can result in the loss of market quota in its home market. In other words, a bank's expansion abroad can sometimes be a defensive reaction to avoid losing important corporate clients at home. This "defensive reaction" hypothesis was first offered by Grubel (1977) for US banks' decision to move overseas (the so called "second wave" of banking internationalization, starting in the 1960s).

Also, a common origin, either historical, linguistic or both, can significantly reduce the costs of operating abroad while facilitating the exploitation of efficiencies or competitive advantages. A common origin may lead to advantages in product differentiation (Swoboda (1990)), knowledge transfer (Guillén and Tschoegl (1999)) or even to a reduction in the cost of capital. This could be the case if the funding locally is easily obtained because of the cultural proximity.

As concerns efficiency, the main factors mentioned in the literature are the size of the bank, its degree of internationalization and product and distribution channels. First, a large size enables banks to translate their scale efficiencies to foreign markets at a relatively low cost and to compete with local institutions even after taking into account the extra costs faced by foreign competitors (Terrell (1979), Tschoegl (1983), and Sabi (1988)). The importance of size depends heavily on the kind of activity developed by the foreign firm in the host market. If the business model implies a duplication of costs, scale efficiencies will be difficult to attain. This is why some authors (for example, Casson (1990)) argue that a model based on subsidiaries with a retail focus is unlikely to benefit from large gains in efficiency, while a branch model would if directed to wholesale or investment banking markets. Second, the degree of internationalization is also relevant since banks with a large and geographically diversified customer base will be able to reduce transaction costs (Ursacki and Vertinsky (1992)). Thirdly, the use of their own distribution channels may imply large gains in efficiency, particularly in developing countries where the supply of certain banking services is generally poorer or sometimes nonexistent. In this case, subsidiaries oriented towards retail banking can certainly profit from product efficiencies. This is even more the case if foreign banks share the same culture and language with the host country since practically no change will be required in the products offered. 
Finally, risk diversification is another important motive for financial FDI in the theoretical literature. Banks can diversify their income base by operating in a foreign country, obtaining gains in terms of their risk-return profile (Aggarwal and Durnford (1989), and Berger and de Young (2001)). The importance of these gains will be closely related to the extent of financial market imperfections, which render diversification by a final investor less worthy than diversification by banks' local operations. In the case of financial FDI to emerging economies, informational and legal problems for individual investors may explain why banks prefer to operate locally in a foreign country. In fact, the existence of these barriers to the mobility of capital could constitute a strong incentive for FDI on its own, if international banks are able to build a geographically diversified portfolio at a lower cost than an individual investor could (Errunza and Senbet (1981)). There are a number of factors which determine how much banks diversify their income base when operating in a foreign country, many of which are probably macroeconomic in their nature, such as the business cycle, the interest rate structure, and the exchange rate. Unfortunately, no theoretical literature exists yet modelling foreign banks financial FDI decisions on the basis of these risk diversification factors. Finally, a related issue is the approach to risk of banks expanding abroad. Repullo (2000) argues that banks prefer to open branches ${ }^{16}$ in relatively riskier countries but with generous deposit guarantee schemes.

Other microeconomic/behavioural theories of financial FDI have focused on the role of strategic behaviour. This strain of the literature introduces the notion that internationalization decisions might be conditioned by the competitive structure of a bank's home market. Knickerbocker (1973) presents the hypothesis that, once a bank has started the process of internationalization, its home markets rivals might follow on the basis of oligopolistic reaction. The pattern of competitor responses, however, is not clearly established by existing theories. Rival banks could choose to expand in the same countries as the leader or, alternatively, a pattern of mutual forbearance might emerge, where a firm avoids markets where a competitor has already established itself.

\section{Macroeconomic framework}

As previously mentioned, macroeconomic and general financial conditions haven been hardly analyzed in the theoretical literature of financial FDI. This is why we focus on theories explaining general FDI. These may be classified in two broad groups.

\footnotetext{
${ }^{16}$ The extension of this analysis to subsidiaries remains an interesting area for future research
} 
First, general equilibrium models compare trade and FDI on the basis of the relative factor endowments, transport costs and opportunities for knowledge transfer (Markusen and Makus (2001), and Helpman (1987)). Second, financial conditions-related theories are based on hypothesis of imperfect capital markets. In this vein, the relative wealth hypothesis of Froot and Stein (1991) focuses on the effects of exchange rates movements in general FDI flows. A depreciation of the local currency increases the relative wealth of foreign investors, allowing them to outbid local rivals for profitable projects. Klein, Peek and Rosengren (2000) offer another explanation based on differences in the relative availability of credit to international investors versus local investors.

Only financial conditions theories have received some attention in the specific case of financial FDI. Some authors have related the entry of Japanese banks in the US to the relative undervaluation of US bank stocks (Goldberg and Saunders (1981)), which, in line with the relative wealth hypothesis, could be the result of a depreciated exchange rate. Given the highly leveraged nature of banking activities, many authors have noted that small international differences in the cost of capital, motivated by relative differences in the access to credit, might give banks headquartered in countries with low costs of capital a competitive advantage over their rivals (see, among others, Aliber (1984)). This lower cost of capital would also result in higher $\mathrm{Q}$ ratios ${ }^{17}$, making the expansion of banking activities easier.

Notwithstanding these attempts, the lack of specific extensions of macroeconomic theories for financial FDI is surprising given the importance of this sector in the surge in FDI and the caveats of micro-organizational theories in explaining financial FDI. One possibility would be to compare cross-border bank loans to trade, in the above-mentioned general equilibrium models and foreign banks' local activity to FDI. Another possibility would be to model the role of financial factors in banks' investment decisions, perhaps in a risk diversification framework, as previously mentioned.

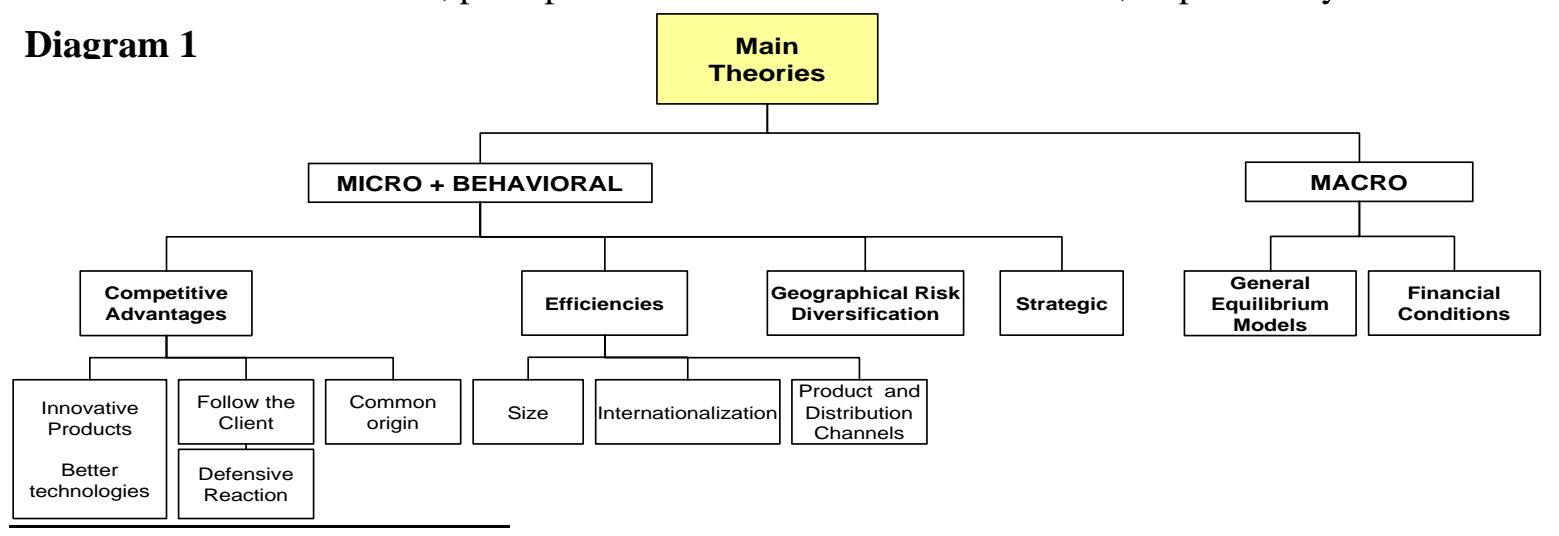

${ }^{17}$ Tobin's Q is usually proxied by the market to book value ratio. In typical Q models, firms invest whenever their Q ratio exceeds one. 


\section{THE DETERMINANTS OF FINANCIAL FDI IN THE EMPIRICAL LITERATURE}

Given the scarcity of theoretical frameworks for financial FDI, particularly macroeconomic ones, the empirical analysis is also relatively limited and has mostly adopted a non structural approach. Furthermore, most of it analyzes the US experience with a number of exceptions, such as Moshirian and Van der Laan (1998) and Buch (2000) for Germany; Aggarwal (1993), Yamory (1998), Nakamura and Oyama (1998) and Klein, Peek and Rosengren (2000) for Japan (1998); and Nieri (1994), Crecchia (1996), De Chirico (1999) and Di Antonio, Mariotti and Piscitello (2003)) for Italy.

\section{Microeconomic/behavioural determinants}

Empirical studies testing micro/organizational theories of financial FDI have concentrated on the comparative advantage (mainly information) and efficiency hypotheses and to a much lesser extent on the risk sharing hypothesis (See Diagram 2 below for a breakdown of the main determinants).

The most frequently tested hypothesis of comparative advantage are information-related, particularly the "follow the client" motivation for financial FDI. Most authors have focused on the relation between bilateral trade and financial FDI, or FDI and financial FDI ${ }^{18}$. Regarding the former, Goldberg and Johnson (1990) find that US bank decisions to expand in a foreign country are very much influenced by the amount of bilateral trade between the US and that specific country. Regarding the latter, Goldberg and Saunders (1981a, 1981b) show that non-bank FDI between the US and another country is a relevant factor explaining financial FDI from the US. Yamori (1998) obtains the same result for Japan, and Buch (2000) for German banks. Finally, Focarelli and Pozzolo (2001) confirm the result for all OECD countries. Two important caveats can be applied to most of the results in this literature. First, there may be other reasons -other than the "follow the client" hypothesis - behind the positive relation between trade and/or non-financial FDI and financial FDI. To overcome this omitted variable bias, Seth, Nolle and Mohanty (1998) have tested the "follow the client" hypothesis directly, by examining the lending patterns of banks. Interestingly, they find that the majority of lending by international banks did not go to borrowers from its home country, a result at odds with the notion that banks expand mainly to serve their home clients abroad. Second, most of the existing evidence refers to financial FDI to industrialized countries, where the case for "follow the client" behaviour is much stronger. In emerging markets economies, non-financial FDI may have been limited by the lack of adequate financial services in the host countries. Thus, foreign bank entry

\footnotetext{
${ }^{18}$ Note that the two could be complementary. In fact, Di Antonio, Mariotti and Piscitello (2003) find that both trade and general FDI are significant determinants of financial FDI for Italian banks
} 
may be a pre-requisite for non-financial FDI and not a consequence. Although existing empirical evidence is not conclusive, Miller and Parkhe (1998) show, using US data, that higher general FDI to a developing country is not related to higher financial FDI.

On common origin as a comparative advantage, there is a broad consensus that this variable plays a significant role in bank's decicision to invest abroad. For example, Galindo, Micco and Serra (2003) show that, as expected, colonial links and language help explain why banks choose to expand in certain countries and not in others.

As regards efficiencies, most studies find that bank size is significant in determining a bank's decision to invest abroad (Grosse and Golberg (1991), Ursacki and Vertinsky (1992), Williams (1996, 1998), Berger et al. (1999) and Di Antonio, Mariotti and Piscitello (2003)). This evidence is reinforced by numerous studies showing that the size of the host country or the size of its financial system are also relevant (see Di Antonio, Mariotti and Piscitello (2003)). In light of this evidence, there is growing consensus about the importance of economies of scale as a motive for financial FDI. Di Antonio, Mariotti and Piscitello (2003) find international experience - measured the number of countries a bank operates in and the number of years since it started its operations - crucially important for banks to expand abroad. Another potential source of efficiencies, mentioned in the theoretical literature, are common product and distribution channels. Guillén and Tschoegl (1999) document the relevance of these efficiencies for the case of Spanish banks' expansion into Latin America. Focarelli and Pozzolo (2000) findings also support their importance, showing that international banks from OECD countries prefer to expand in less efficient banking system. Miller and Parkhe (1998), however, find that banks prefer to invest in countries where the banking system is more developed, as a way to improve their own product and distribution channels rather than exporting them, among other reasons.

The risk sharing hypothesis is supported by a number of studies. Amihud, DeLong and Saunders (2002) find a low correlation - even negative - between banks' earnings in industrial countries. In the same vein, Buch and DeLong (2001) show that geographical distance is a key determinant of financial FDI for most G7 countries, except the US. Another related question is the approach to risk that banks take when expanding abroad. Acharya, Hasan and Saunders (2002) report that Italian banks with low initial risk obtain more profitability and less risk (in terms of non performing loans and volatility of their stocks) when they expand abroad. However, for those banks with a higher risk profile, expanding abroad implies higher profitability but also more risk. Amihud, DeLong and 
Saunders (2001) find that cross-border mergers do not, on average, increase or decrease the total risk of the acquirer.

As regards strategic motivations for international expansions, García Blandon (2003) tests the first mover hypothesis and finds that banks with the strongest advantages were the first to enter the Spanish financial system. Empirical evidence on the pattern of responses to the international expansion of a competitor bank is mixed. The results in Choi, Tschoegl and Chow-Ming (1996) support the mutual forbearance hypothesis among major banks in international financial centres. On the other hand, Guillén and Tschoegl (1999) present evidence that Spanish banks replicated the localization decisions of their competitors during their expansion in Latin America.

\section{Macroeconomic determinants}

The lack of macroeconomic theories on financial FDI explains the scarcity of empirical analysis in this area. To bridge this gap, this section will review the empirical literature on the determinants of general FDI, together with the very few specific studies on financial FDI. Macroeconomic determinants of FDI, are generally classified in two major groups: push (or home-country related factors), and pull (or host country-related ones). For the first there is no literature on the specific case of financial FDI while there is for the second.

Among the push factors, the home country's economic cycle has recently attracted large attention in the FDI literature although there is no clear consensus on its impact. On the one hand, home country growth increases firm's wealth and relaxes the financial constraint that FDI may face. On the other hand, to the extent that home productivity of capital is positively correlated with growth, expansions should be associated with a relative increase in home expected returns, reducing the attractiveness of FDI. In principle, the same arguments would seem valid for financial FDI but no literature exists yet. The empirical evidence on general FDI is also not totally conclusive. Thomsen (2000) shows that global FDI grows less when the U.S. is in recession. In the same vein, Barrell and Pain (1996) find that growth in industrialised economies is positively related to US FDI. Albuquerque, Loayza and Serven (2002) find that world per capita growth positively affects inflows to developing countries while it is not significant for developed ones. This is in line with Calvo et al. (2001) results. Nakamura and Oyama (1998) obtain a significant procyclality of FDI flows from Japan to East Asia $^{19}$ but not for FDI from the US to Asia. Levi-Yeyati, Panizza and Stein (2002),

19 This result applies mostly to countries with a high economic integration with the Japanese economy 
however, show evidence that FDI flows from the US and Europe to emerging countries are countercyclical, not only with respect to output but also interest rates, while Japanese international investment displays no cyclical behaviour or mild prociclicality.

Another important push factor in the FDI literature is the level of interest rates in the home country. There is a general consensus that high real interest rates hamper FDI, other things given. Albuquerque, Loayza and Serven (2002) find a significant and negative relation between the yield of the US T-Bill and FDI flows, both to industrialised and developing countries. Calvo et al. (2001) show that FDI flows to emerging countries are lower during U.S. monetary tightenings. This result is corroborated by Levy-Yeyati, Panizza and Stein (2002) except for Japanese FDI. Although no empirical literature exists for the specific case of financial FDI, the same result should in principle be expected since low interest rates at home, leading to narrow interest margins and lower costs of capital at home, are one of the main reasons offered by banks to explain their operations abroad, particularly in emerging countries where margins tend to be much larger. This is corroborated by some case studies of Spanish banks (Guillén and Tschoegl (1999)).

As pointed in the theoretical literature, financial conditions in the home country affect the decision to invest abroad. Wealth factors, proxied by the exchange rate, have been extensively analysed in the FDI literature without reaching a consensus. Blonigen (1997) shows that the yen appreciation fostered FDI by Japanese firms. In the same vein, Barrell and Pain (1996) find that expected appreciations in the dollar postpone FDI from US companies. Finally, Reinhart and Reinhart (2002) show that periods of high variability in G-3 exchange rates were accompanied by larger FDI flows. The stock market value, less frequently used as a proxy of wealth factors, yields similar results. In particular, Klein and Rosengren (1994) find that a higher stock market value of firms from seven different home countries favours their investment abroad. Finally, another important determinant of financial conditions is the relative access to credit. Klein, Peek and Rosengren (2000) show that the poorer relative access to credit of Japanese firms during the 1990s explains the fall in Japanese FDI notwithstanding the appreciation of the yen which, according to the relative wealth hypothesis, should have fostered Japanese direct investment in the US.

In contrast with push factors, pull factors have been analyzed empirically for the specific case of financial FDI. The host country's (expected) economic growth is found to be a driving force of international banking (Focarelli and Pozzolo (2001)). Another related variable is the development of the financial system in the host country. The same authors show that foreign banks prefer to operate in countries with a relatively developed and not too concentrated financial system. Economic 
integration between the home and host countries also fosters financial FDI, as already mentioned when reviewing the "follow the client" hypothesis. Macroeconomic volatility, in turn, appears to hamper financial FDI (Grosse and Goldberg (1991), Fisher and Molyneux (1996) and Yamori (1998)). Others pull factors are specific of investment in industrial countries, such as ensuring a stable deposit base (Walter and Gray (1983))

There are also a number of institutional factors which appear to determine financial FDI. For simplicity, we apply the same distinction of pull and push factors. Among the push factors, a very relevant one is the existence of domestic restrictions limiting banks' operations at home (Buch and DeLong (2001)). As regards pull factors, the openness of the host country to the establishment of new foreign branches and subsidiaries is key, as well as tax incentives (Nigh, Cho and Krishnan (1986), Goldberg and Johnson (1990), Golberg and Grosse (1994), Sagari (1992), Barth et al. (2001), and Milher and Parkhe (1998)). In the same vein, Focarelli and Pozzolo (2001) show that banks prefer to acquire equity interests in countries where either regulatory restrictions on banking activities are low or the market is less concentrated ${ }^{20}$. Other relevant pull factor is the legal system, in particular the protection of creditor rights and the quality of bankruptcy procedures. ${ }^{21}$ Finally, high per capita income in the host country, used as a proxy for profit opportunities, fosters financial FDI (Brealey and Kaplanis (1996), Yamori (1998) and Buch (2000)). In the same vein Claessens et al. (2000) show, for a large number of countries, that banks are attracted to markets with high profitability an income per capita, as well as low taxes.

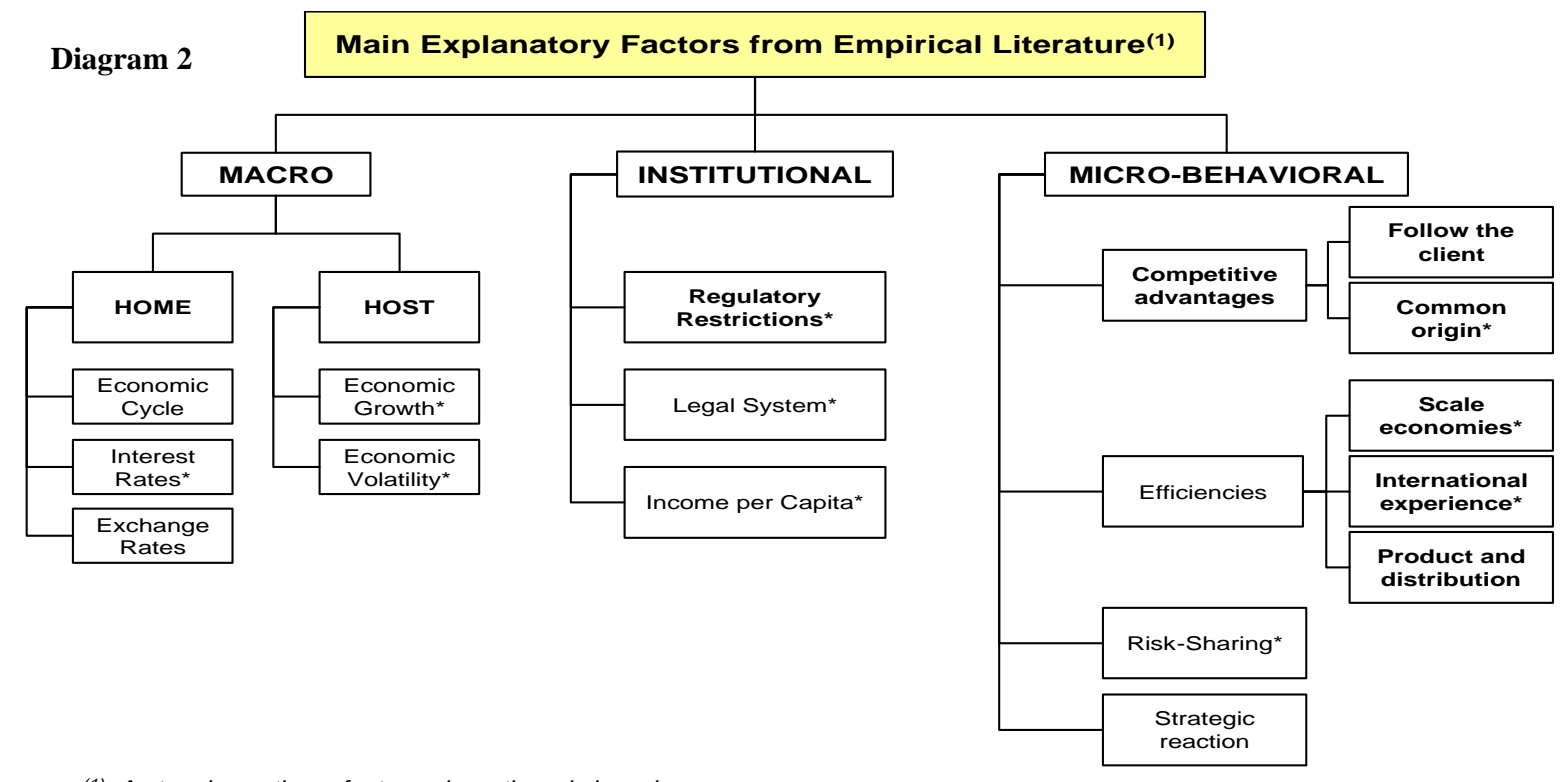

(1) A star shows those factors where there is broad consensus

\footnotetext{
${ }^{20}$ The result does not hold for the case of branches

${ }^{21}$ Many authors have explored this issue. See Focarelli and Pozzolo (2001) and Buch and DeLong (2001)
} 


\section{EFFECTS OF FINANCIAL FDI ON THE HOME COUNTRY}

While the factors explaining financial FDI, particularly pull ones, have been explored to some extent in the empirical literature, the effects that it may have on the home country are virtually unknown. The situation is very different for the impact on the host country, where a large amount of empirical analysis has been conducted, looking at its impact on economic and financial development, as well as financial efficiency and stability, among others ${ }^{22}$. We, therefore, review the general FDI literature on this issue and attempt to draw some parallels with financial FDI.

The effects of general FDI on the home country's economy have been classified in three groups: financial, production and employment-related, and structural ones. ${ }^{23}$ Financial effects relate to the possibility that investment abroad substitutes investment at home. If a firm's cost of capital is not constant, domestic and foreign projects will compete for the use of relatively cheap (and scarce) internally generated funds. Stevens and Lipsey (1992) find some degree of substitution between domestic and foreign investment by U.S. firms. In the same vein, Feldstein (1994) concludes that there is an almost one to one relationship between FDI outflows and U.S. domestic investment. ${ }^{24}$ For the case of financial FDI, one could think that international banks have large financing possibilities (including direct funding in the host country), which should limit the impact of their expansion on financial conditions at home. This, however, may change in the event of a crisis in a host country of systemic importance for the parent bank.

The interest on the effects of FDI on production lies primarily on possible changes in the geographical distribution of productive activities and employment. On the first issue, the link between a country's exports and the amount of FDI that firms conduct has been analyzed empirically, in order to determine whether there is substitution between domestic exports and foreign production. This hypothesis is hardly supported in the literature; in fact there is either no relationship or a moderate amount of complementarity between trade and FDI (Blomström and Koko (1994) and Lipsey (2002)). A way to look at this issue for the specific case of financial FDI is to compare the evolution of cross-border lending and local activity in a foreign country. While there is virtually no

\footnotetext{
${ }^{22}$ See Clarkel et al. (2002), and Sousa (2003) for a review of the literature

${ }^{23}$ This section draws heavily from the literature review of Lipsey (2002).

${ }^{24}$ Since most countries do not have detailed statistics on direct foreign investment outflows, most of the results are limited to the United States, Japan and Sweden
} 
literature on this issue, anecdotal evidence shows that the relation is weak, particularly for banks operating in the retail sector abroad.

The second aspect related to production is the potential reduction of domestic employment due to the multinationals' ability to deploy operations in low-wage countries. A number of studies analyze the effects of FDI outflows on the level of employment in source countries. Blomström, Fors and Lipsey (1997) show that U.S. multinationals do indeed reduce their labour intensity after an increase in foreign production, particularly if located in developing countries. However, they find the opposite for Swedish multinationals. These somewhat contradictory results may be explained by the differences in multinationals' strategies of international expansion. While U.S. firms seem to pursuit factor cost advantages, Swedish firms' investment decisions have been driven by natural resources and technological advantages. The case of Japan is less clear. While their firms' strategies are similar to those of US firms, employment is not reduced. This might be related to life-time employment habits at home. As for financial FDI, there is no available evidence of its impact on the level of employment in the banking sector of the home country. In any event, one would expect a very marginal - if not positive impact - particularly for those banks operating retail abroad. The reason is the lack of large economies of scale or substitution of service provision in the home country.

Finally, investing abroad may also affect the structure of the economy. The literature has focused mainly on two aspects. First, the composition of exports. While FDI may not substitute exports in aggregate terms, data on Swedish firms present clear evidence of a change in the composition of exports following the internationalisation of domestic firms (Swedenborg (1982)). This shift results in a higher proportion of intermediate goods as home plants tend to provide inputs for foreign plants. As Blomström and Koko (1994) point out, the pattern and the consequences of specialization on intermediate inputs are likely to depend on the comparative advantages of the investor country. Second, FDI activity may also change the composition of labour demand in the home country. The most common hypothesis is that, as firms move low-skill and low-cost activities to developing countries, labour demand of white-collar workers will increase relative to that of blue-collar. Available studies show that this needs not be the case. Using hourly wages as a proxy for skill, Kravis and Lipsey (1988) did not find a clear relationship between skill intensity and foreign production. In the Swedish case, FDI in developing countries resulted in increased demand for both skilled and unskilled workers at home (Blomström, Fors and Lipsey (1997)). Furthermore, investment in developed economies reduced the demand for white collar workers but increased nonskilled labour intensity. As before, for the financial FDI, evidence is unavailable, but one could think that the same line of argument should apply since banks operating abroad will need to increase the 
share of skilled labour because only these are expatriated to the branches or subsidiaries abroad. As for the empirical evidence on general FDI, the impact could be marginal particularly in cases where international banks acquire existing banks and keep local management.

Based on this evidence, there are good to reasons to expect the effects of financial FDI on the home country to be weak. Of course, the idiosyncratic characteristics of financial FDI, especially if directed to developing countries, raise other important questions that have not received enough attention in the literature. In particular, its effects on the profitability and systemic risk of home's financial system still need to be addressed beyond the results obtained by Amihud, DeLong and Saunders (2001), among others.

\section{CONCLUSIONS AND SUGGESTIONS FOR FUTURE RESEARCH}

This paper reviews the theoretical literature explaining financial FDI, as well as the empirical results on the determinants of financial FDI and its potential effects for the home country. From this review, several conclusions can be drawn.

First, the theoretical literature, which is still scarce particularly for macroeconomic theories, is still too concentrated on the so-called "second wave" of banks' international expansion, where information advantages and "follow the client" motives were crucial. No good theories exist yet to explain the "third wave" of bank internationalization, characterized by a surge in local operations in emerging countries. Risk diversification theories seem particularly adapted to explain this reality.

Second, some empirical work has been done on the pull factors determining financial FDI but virtually none exists for push factors. The same is true for the effect of financial FDI on the home country. This is a consequence of the host country's focus that the literature on financial FDI has had, particularly in the most recent years. Partially as a result, there is still poor knowledge of the determinants of financial FDI, and to some extent also FDI in general. The consensus is stronger for institutional factors, the host country's income per capita, economic growth and volatility. There is also broad consensus that size matters for banks to expand abroad, as well as risk sharing and follow the client motivations. However, there are important factors for which no consensus emerges, such as the role of the home country's economic cycle. In addition, more efforts would be needed to explain the differences between operating in emerging - rather than industrial - countries and between branches and subsidiaries, following Focarelli and Pozzolo (2001) tentative results. 
Finally, the effects on financial FDI on the home country are virtually unknown. The empirical literature on general FDI points to potentially significant financial effects (substitution of domestic investment by outward FDI), while the effects on production, employment and the structure of the economy seem weak. In any event, exploring the likely consequences of financial FDI on the profitability and systemic risk of the home country seems particularly important, since these are potentially the most important effects for the financial system while being generally significant for other sectors too. This is even more so the case for countries where financial FDI has concentrated in a particular emerging region (i.e., Spain in Latin America and Austria in Central and Eastern Europe). Along these lines, it would also be interesting to compare calm periods with crisis ones to see how the effects on the home country differ. 


\section{REFERENCES}

Aggarwal, R. and Durnford, J. (1989) Market assessment of international banking activity: a study of US bank holding companies. Quarterly Review of Economics and Business 29: 58-67

Aggarwal, R. (1993) The global expansion of Japanese financial service firms: role of domestic economic and regulatory policies. In coalitions and Competition: The Globalization of Professional Business Services, Aharoni Y. Routledge: London.

Acharya V., Hasan I. and Saunders A. (2002) The Effects of Focus and Diversification on Bank Risk and Return: Evidence from Individual Bank Loan Portfolios. New York University Salomon Center for the Study of Financial Institutions Working Paper

Albuquerque R., Loayza, N. and Serven, L. (2002) World market integration through the lens of foreign direct investors. Forthcoming Review of Economic Studies.

Aliber RZ. (1984) International banking: a survey. Journal of Money, Credit and Banking$661-712$

Amihud Y., DeLong G. L. and Saunders A. (2003) The Effects of Cross-Border Bank Mergers on Bank Risk and Value. Journal of International Money and Finance

Barrel, R. and Pain, N. (1996) An econometric analysis of U.S. foreign direct investment. The Review of Economic and Statistics, 78(2), 200-207.

Berger and de Young (2001) The effects of geographic expansion on bank efficiency. Journal of Financial Services Research.

Brealey RA, and Kaplanis EC (1996) The determination of foreign banking location. Journal of Internatinal Money and Finance.-577-597

Barth, J. Caprio, G. and Levine, R., (2001), "Banking Systems Around the Globe: Do Regulation and Ownership Affect Performance and Stability?" in Mishkin, F. (ed.), Prudential Regulation and Supervision: What Works and What Doesn't, National Bureau of Economic Research.

Ball, C. and Tschoegl, A. (1982) The decision to establish a foreign bank branch or subsidiary: an application of binary classification procedures. The Journal of Financial and Quantitative Analysis, 17(3), 411-424. 
Berger A. N., R. S. Demsetz, P. E. Strahan (1999), The Consolidation of the Financial Services Industry: Causes, Consequences, and Implications for the Future, Journal of Banking and Finance, 23, pp.135-194.

Blomström, M. and Kokko, A. (1994) Home country effects of foreign direct investment: evidence from Sweden. NBER Working Paper 4639.

Blomström, M., Fors, G. and Lipsey, R. (1997) Foreign direct investment and employment: home country experience in the United States and Sweden. NBER Working Paper 6205.

Blonigen B. (1997) Firm specific assets and the link between exchange rates and foreign direct investment, The American Economic Review Vol. 87, 3 pp. 447-465

Brimmer, A. and Dahl, F. (1975) Growth of American international banking: implications for public policy. Journal of Finance, 30, 341-363.

Buch, C., (2000), "Why do Banks go Abroad - Evidence from German Data," Financial Markets, Institutions and Instruments, 9(1): 33-67.

Buch, C. M., and G. L. DeLong (2001), Cross-Border Bank Mergers: What Lures the Rare Animal?, (Kiel Institute of World Economics, Kiel GE).

Buckley P. J. and Casson M. (1991), The future of the multinational enterprise, MacMillan, London

Choi S., Daekun P. and Tschoegl E. (1996). Banks and the World's Major BankingCenters, 1990. Weltwirtschaftliches Archiv 132: 774-793.

Calvo, G., Fernández-Arias E., Reinhart, C. and Talvi, E. (2001) The growth-interest rate cycle in the United States and its consequences for emerging markets. Inter-American Development Bank Working Paper 458.

Casson, M. (1990) Evolution of multinational banks: a theoretical perspective. In G. Jones (ed.) Banks as Multinationals (pp.14-29). London: Routledge.

Claessens, S., A. Demirgüç-Kunt, and H. Huizinga (2000), The Role of Foreign Banks in Domestic Banking Systems. In S. Claessens and M. Jansen, (eds.), The Internationalization of Financial Services: Issues and Lessons for Developing Countries, Boston, MA, Kluwer Academic Press. 
Clarke, G., Cull, R., Peria, M., Sánchez, S., (2001), Foreign bank entry: experience, implications for developing countries, and agenda for future research. World bank policy research paper, 2698

Crecchia, C. (1996) Banche italiane e mercati esteri: il processo di internazionalizzazione del sistema bancario italiano. Il Mulino: Bologna

De Chirico, R. (1999) The initial phases of Italian banks'expansion abroad, 1900-1931. Financial History Review- 7-24

De Nicoló, G., Bartholomew, P., Zaman, J. and Zephirin, M. (2003) Bank consolidation, internationalization, and conglomeration: trends and implications for financial risk. IMF Working Paper WP 03/158.

Dunning, J. (1977) Trade, location of economic activity and the MNE: a search for an eclectic approach. In B.Ohlin, Hesselborn P. and Wijkman, P. (eds.), The International Allocation of Economic Activity, (pp. 395-431), proceeding of a Nobel Symposium held in Stockholm. London: MacMillan Press.

Dufey, G. and Giddy, I. (1981) Innovation in the international financial markets. Journal of International Business Studies, Fall 1981, 33-51.

Engwall, L. and Wallenstal, M. (1998) Tit for tat in small steps: the internationalisation of Swedish banks. Scandivavian Journal of Management- 147-155

Errunza, V. and Senbet L. (1981) The Effects of International Operations on the Market Value of the Firm: Theory and Evidence. Journal of Finance 36 (2) 401-417.

Feldstein, M. (1994) The effects of outbound foreign direct investment on the domestic capital stock. NBER Working Paper 4668.

Fisher, A., and P. Molyneux (1996), A note on the determinants of foreign bank activity in London between 1980 and 1989, Applied Financial Economics, 6, pp. 271- 277.

Froot, K. and Stein, J. (1991) Exchange rates and foreign direct investment: an imperfect capital markets approach. Quarterly Journal of Economics, 106(4), 1191-1217.

Focarelli, D., and A. F. Pozzolo, 2001, The Patterns of Cross-Border Bank Mergers and Shareholdings in OECD Countries, Journal of Banking and Finance 25, 2305-2337.

Galindo,, A., Micco, A. and Serra, C., (2003), Better the Devil that You Know: Evidence on Entry Costs Faced by Foreign Banks, IADB Working Paper \#477. 
Gallego, S., García Herrero, A., and Luna, C. (2003) Investing in the financial sector of emerging countries: Potential risks and how to manage them. Revista de Estabilidad Financiera, octubre 2003.

García Blandon, J. (2003) The timing of foreign direct investment under uncertainty: Evidence from the Spanish banking sector.

García Herrero, A. , Santillán, J., Gallego, S., Cuadro, L., and Egea, C. (2002) Latin American financial development in perspective. Documento de Trabajo 216 del Banco de España.

Guillén, M. and Tschoegl, A., (1999), "At Last the Internationalisation of Retail Banking? The Case of the Spanish Banks in Latin America," Wharton Financial Institutions Center Working Paper, 99-41.

Golberg, L G. and Grosse, R. (1994) Location choice of foreign banks in the United States. Journal of Economics and Business - 367-379

Goldberg, L. G. and D. Johnson (1990), "The Determinants of U.S. Banking Activity Abroad", Journal of International Money and Finance, 9, pp. 123-37.

Goldberg, L. and Saunders, A., (1981a) The Determinants of Foreign Banking Activity in the Untited States, Journal of Banking and Finance, 5:17-32.

Goldberg, L. and Saunders, A., (1981b) The Growth of Organisational Forms of Foreign Banks in the US: A Note, Journal of Money, Credit and Banking, 13(3): 365-374.

Gray, M. and Gray, H. (1981) The multinational bank: a financial MNC? Journal of Banking and Finance, 5, 33-63.

Grosse, R. and Goldberg L. G. (1991), Foreign Bank Activity in the United States: an Analysis by Country of Origin, Journal of Banking and Finance, 15, pp. 1092-112.

Grubel, H. (1977) A theory of multinational banking. Banca Nazionale del Lavoro Quarterly Review, December, 349-363.

Helpman, E. (1987) A simple theory of trade with multinational corporations. Journal of Political Economy 92, 451-471.

Hymer, S.H. (1969), The International Operations of National Firms: A Study of Direct Foreign Investment, Ph.D. Dissertation, MIT. 
International Monetary Fund (2003), "Foreign Direct investment in Emerging Countries", Chapter X of the World Economic Outlook, September

Jacobsen, SF. and Tshoegl AE. (1999) The Norvegian banks in the Nordic consortia: a case of international strategic alliances in banking. Industrial and Corporate Change - 137-163

Jones G. (1990) Banks as multinationals. In G. Jones (ed.) Banks as Multinationals (pp.1-13). London: Routledge.

Klein, Michael W. and Rosengren, Eric S. (1994) The real exchange rate and foreign direct investment in the United States. Journal of international Economics, 1994, 36, pp 373-89

Klein, M., Peek, J. and Rosengren E. (2000) Troubled banks, impaired foreign direct investment: the role of relative access to credit. NBER Working Paper 7845.

Knickerbocker, F. (1973) Oligopolistic reaction and multinational enterprise. Harvard University.

Kravis, I. and Lipsey, R. (1988) The effects of multinational firms' foreign operations on their domestic employment. NBER Working Paper 2760.

Lipsey, R. (2002) Home and Host country effects of FDI. Paper for ISIT Conference on Challenges to Globalization held in Lidingö, Sweden.

Levy-Yeyati E., Panizza U. and Stein E. (2002) The cyclical nature of North-South FDI flows. Inter-American Development Bank.

Marichal, C. (1997) Nation building and the origins of banking in Latin America, 1850-1930. In Alice Teichova, Ginette Kurgan-van Hentenryk and Dieter Ziegler, eds. Banking, Trade and Industry: Europe, America and Asia from the thirteenth to the twentieth century. Cambridge: Cambridge University Press.

Markusen, J. and Maskus, K. (2001) General-equilibrium approaches to the multinational firm: a review of the theory and evidence. NBER Working Paper 8334.

Mathieson, D J and Roldos, J. (2001) Foreign Banks in Emerging Markets. In 'Open Doors: Foreign Participation in Financial Systems in Developing Countries', Litan, R, Masson, P, and Pomerleano, M, (editors), Brookings Institution Press, 2001.

Miller, S.R., and A. Parkhe (1998), Patterns in the Expansion of U.S. Banks' Foreign Operations, Journal of International Business Studies, 29, pp. 359-390. 
Merret, D. (1990) Paradise lost? British banks in Australia. In G. Jones (ed.) Banks as Multinationals (pp.62-84). London: Routledge.

Mody, A. and Razin, A. and Sadka, E. (2003) The role of information in driving FDI flows: host-country transparency and source-country specialization.

Moshirian, F. and Van der Laan, A. (1998) Trade in financial services and the determinants of banks' foreign assets. Journal of Multinational Financial Management - 23-38

Nakamura S. and Oyama T (1998), The Determinants of Foreign Direct Investment from Japan and the United States to East Asian Countries, and the Linkage between FDI and Trade, Bank of Japan Working Paper 98-11

Nieri, L. (1994) L'espansione all'estero delle banche italiane: aspetti strutturali e problematiche gestionali. Il Mulino: Bologna

Nigh, D., Cho, K. and Krishnan, S. (1986) The role of location-related factors in U.S. banking involvement abroad: an empirical examination. Journal of International Business Studies, 17(3), 1986, 59-72.

Reinhart, C. and Reinhart V. (2002) What hurts most? G-3 exchange rate or interest rate volatility?. Paper prepared for NBER Conference on Currency Crises.

Repullo R. (2000) A model of takeover by foreign banks, CEMFI Working Paper 0015

Sabi M. (1988), An application of the theory o foreign direct investment to multinational banking in LDCs, Journal of International Business Studies, Volume 19, Issue 3.

Sagari, S. B. (1992), United States Foreign Direct Investment in the Banking Industry, Transnational Corporations, pp. 93-123.

Seth, R., Nolle, D. and Mohanty, S., (1998) Do Bank Follow Their Customers Abroad?, Financial Markets, Institutions and Instruments, 7(4): 1-25.

Soussa , F. (2003) A Note on Banking FDI in Emerging Markets: Literature Review and Evidence from M\&A Data. Preliminary Draft. Bank of England.

Stevens, G. and Lipsey, R. (1992) Interactions between domestic and foreign investment. Journal of International Money and Finance, 11,40-62.

Swedenborg, Birgitta (1982), Svensk Industri I Utlandet, En Analys av Drivkrafter och Effekter, Stockholm, Industriens Utredningsinstitut. 
Swoboda, A., (1990), Swiss banking after 1992, in J. Dermine, ed., European banking in the 1990s, (Basil Balckwell).

Terrell H. (1979), US banks in Japan and Japanese banks in the US: An empirical comparison, Federal Reserve Bank of San Francisco, Economic Review, Summer: 18-30

Thomsen S. (2000) Investment patterns in a longer-term perspective. OECD Working Papers on International Investment 2000/2.

Tschoegl, A. E. (1983), Size, Growth, And Transnationality Among the World's Largest Banks, Journal of Business, pp.187-201.

Ursacki, T. and I. Vertinsky (1992), Choice of Entry Timing and Scale by Foreign Banks in Japan and Korea, Journal of Banking and Finance, 16, , pp. 405-21.

Walter, I. and Gray H. (1983) Protectionism and international banking, Sectoral efficiency, competitive structure and national policy, Journal of Banking and Finance 7, 597-609.

Williams, B. (1996), Determinants of the Performance of Japanese Financial Institutions in Australia 1987-1992, Applied Economics, 28, pp. 1153- 65.

Williams, B. (1997) Positive Theories of Multinational Banking: Eclectic Theory versusInternalization Theory. Journal of Economic Surveys 11 (1), pp. 71-100.

Williams, B. (1998), Factors Affecting the Performance of Foreign-Owned Banks in Australia: a Cross-Sectional Study, Journal of Banking and Finance, 22, pp. 197-219.

Yamori, N. (1998), A Note on the Location Choice of Multinational Banks: the Case of Japanese Financial Institutions, Journal of Banking and Finance, 22, pp. 109-20. 